\title{
Pathogenic potential of Escherichia coli from various sources in Port Harcourt, Rivers State, Nigeria
}

\author{
*OTOKUNEFOR, K; NYEMA, P
}

\author{
Department of Microbiology, Faculty of Science, University of Port Harcourt, PMB 5323, Choba, Port Harcourt, Rivers State. \\ *Corresponding Author Email: kome.otokunefor@uniport.edu.ng
}

\begin{abstract}
Despite its occurrence as a commensal, Escherichia coli is also notorious as a pathogen. One variation between these commensals and pathogens is the presence of specific factors one of which are the pathogenicity islands. One of the most commonly occurring of these is the PAI IV $\mathrm{IV}_{536}$. Potentially pathogenic species have been described in nonclinical settings. This often raises concerns on the role these environments play in transmission. This study therefore aimed at comparing the pathogenic ability of $E$. coli isolates from clinical and non-clinical sources based on the presence of the PAI IV ${ }_{536}$ marker. Thirty-five $E$. coli isolates were analyzed in this study. Following DNA extraction by boiling, the PAI $\mathrm{IV}_{536}$ gene fragment was amplified following standard procedure using the F5'-AAGGATTCGCTGTTACCGGAC-3' and R5'-TCGTCGGGCAGCGTTTCTTCT-3' primer pair. Of the 35 isolates, 13 were from clinical sources and 22 from nonclinical sources. In total, $25.7 \%(9 / 35)$ of the $E$. coli isolates in this study were found to possess the PAI IV S36 $_{53}$ gene. Clinical isolates had a much higher association of $61.5 \%$ with the PAI IV S36 $_{53}$ gene than non-clinical which only had a $4.5 \%$ representation of the PAI IV ${ }_{536}$ gene. This study reports on the detection of PAI IV ${ }_{536}$ in E. coli isolates from Port Harcourt, Rivers State Nigeria and a lower association of this pathogenicity marker with non-clinical isolates.
\end{abstract}

\section{DOI: https://dx.doi.org/10.4314/jasem.v23i5.25}

Copyright: Copyright $\odot 2019$ Otokunefor and Nyema. This is an open access article distributed under the Creative Commons Attribution License (CCL), which permits unrestricted use, distribution, and reproduction in any medium, provided the original work is properly cited.

Dates: Received: 15 April 2019; Revised: 19 May 2019; Accepted 22 May 2019

Keywords: Escherichia coli, clinical vs non-clinical, pathogenicity, PAI IV 536

Escherichia coli is widely known as a commensal found in association with various human and nonhuman systems particularly the gastrointestinal tract, where it exists without causing any observable harm (Allocati et al., 2013, Fratamico et al., 2016). These organisms exist as part of the normal flora of the intestines of humans but are routinely encountered in the environment due to faecal and wastewater discharges (Jang et al., 2017). E coli is however also notorious as a pathogen, notable as the most common human Gram-negative bacterial pathogen isolated in the clinical microbiology laboratory (Poolman and Wacker 2016, Vila et al., 2016). It is notorious for mediating a wide variety of infectious diseases ranging from mild self-limiting to more serious lifethreatening conditions. It is a leading cause of urinary tract infections, diarrheal diseases, bacteremia and meningitis (Vila et al., 2016, Poolman and Wacker 2016).Commensal and pathogenic E. coli differ in the presence of specialized pathogenic and virulence factors in the pathogenic strains. These factors are of a variety of types and include invasins, adhesins, toxins, iron-acquisition systems and type three secretion system (Mainil 2013). These pathogenic strains of $E$. coli commonly develop due to gene acquisition, which provides the acquiring organism with new traits and often a fitness advantage. The genome sizes of the pathogenic variants have been found to differ by up to a million base pairs (Croxen et al., 2013), with an up to $20 \%$ variation found to occur between commensal and pathogen genomes (Ochman and Jones 2000). These extra genes which confer the pathogenic potential belong to a subset of genes referred to as the flexible gene pool. Gain or loss of such genes occurs at specific hotspots distributed all over the genome (Touchon et al., 2009). Some of these virulence genes may be encoded in chromosomal pathogenicity islands (Chekabab et al., 2013), which are a unique class of genomic islands. And these genomic islands have been found to be significant in defining E. coli (van Elsas $e t$ al., 2011). Two studies have noted that a quarter of the genomic content of particular pathogenic strains was made up of genomic islands (Chaudhuri et al., 2010, Perna et al., 2001). Pathogenicity islands (PAIs) are distinct chromosomal mobile genetic elements, obtained by horizontal gene transfer which contribute to genome evolution (Oelschalaeger and Hacker 2004). These elements first described in E. coli (Schmidt and Hensel 2004) are known to carry virulence genes and, in some cases, antibiotic resistance genes. They are generally present in pathogenic strains but absent in non-pathogenic strains 
(Gal-Mor and Finlay 2006). PAIs are generally associated with specific sites of the chromosome and mobility genes and elements. Characteristically, they have a $\mathrm{G}+\mathrm{C}$ content which varies from the surrounding core genome. Several PAIs exist with up to 8 described (Calhau et al., 2015). One of such PAIs is the PAI $\mathrm{IV}_{536}$ initially associated with uropathogenic $E$. coli strain 536. PAI $\mathrm{IV}_{536}$ is a high pathogenicity island notable for its association with yersiniabactin, a siderophore system (Karczmarczyk et al., 2011). This particular pathogenicity island has been found associated with intestinal pathogens, uropathogens, extraintestinal pathogens and even commensals and is often the most commonly detected PAI in enterobacteria (Karczmarczyk et al., 2011, Dobrindt et al., 2002, Sabate et al., 2006, Koga et al., 2014).

Quite often, potentially pathogenic species have been found in non-clinical settings such as poultry environments, ready-to-eat foods, drinking water systems and inanimate surfaces (Otokunefor et al., 2018, Cookey and Otokunefor 2016, Agbagwa and Onyebule 2018). Often, they are found in association with high decrees of drug resistance. And concern has been expressed regarding the transfer of these isolates into the clinical settings and the potential human impact. Few studies have however set out to ascertain the actual pathogenic ability of isolates obtained. This study was therefore aimed at exploring the pathogenic ability of a panel of $E$. coli isolates based on the presence of a PAI IV 536 marker.

\section{MATERIALS AND METHODS}

Bacterial Isolates: Thirty-five E. coli isolates were analyzed in this study. These isolates were obtained from the culture collection of the Bacteriology group of the Medical Microbiology Unit of the University of Port Harcourt.

DNA extraction: The boiling method (Oliveira et al., 2014) was used for DNA extraction in this study. Pure bacterial colonies were boiled in $100 \mu \mathrm{L}$ of molecular grade water for $5 \mathrm{~min}$ and impurities removed by centrifugation at $10,000 \mathrm{~g}$ for $5 \mathrm{~min}$. Bacterial DNA contained in the supernatant was then used in the molecular studies.

Detection of PAI marker: The PAI $\mathrm{IV}_{536}$ gene fragment was detected using previously described primers (Koga et al., 2014). Each amplification reaction mix comprised of $2 \mu 1$ master mix $(5 x), 0.3 \mu 1$ each of forward and reverse primer (10 pmol/ $\mu \mathrm{l}), 2 \mu \mathrm{l}$ of DNA template and $5.4 \mu \mathrm{l}$ of $\mathrm{H}_{2} \mathrm{O}$ in a final volume of $10 \mu 1$. The amplification protocol involved an initial denaturation at $95^{\circ} \mathrm{C}$ for 5 mins followed by 35 cycles of denaturation at $95^{\circ} \mathrm{C}$ for $1 \mathrm{~min}$, annealing at $56^{\circ} \mathrm{C}$ for $30 \mathrm{secs}$ and extension at $72^{\circ} \mathrm{C}$ for $2 \mathrm{~min}$. it ended with a final extension of $72^{\circ} \mathrm{C}$ for 10 mins. Following amplification, PCR products were visualized on $1.5 \%$ agarose gels stained with ethidium bromide.

\section{RESULTS AND DISCUSSION}

Source of Isolates: Identities of the $35 \mathrm{E}$. coli isolates had previously been confirmed using both phenotypic and molecular methods (Otokunefor et al., 2019). Of these 35 isolates, 13 had been obtained from clinical sources and 22 from non-clinical sources.

Detection of PAI IV 536 gene: In total, $25.7 \%$ (9/35) of the $E$. coli isolates in this study were found to possess the PAI $\mathrm{IV}_{536}$ gene. The rate of carriage of this gene was however found to differ based on source of the isolates. Clinical isolates were found to exhibit a higher carriage rate than non-clinical isolates (Figure 1 ), with a $57 \%$ difference in level of carriage.

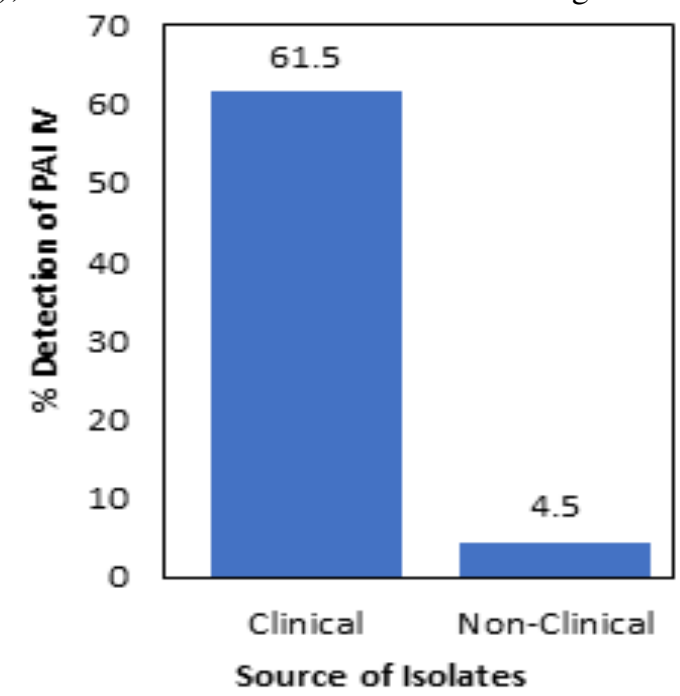

Fig 1: Presence of the pathogenicity island PAI $\mathrm{IV}_{536}$ gene marker in E. coli isolate

Eight pathogenicity islands have commonly been described in $E$. coli isolates. One of the more commonly occurring of these pathogenicity islands is

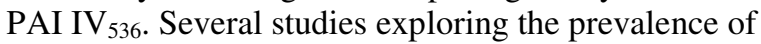
this island in various $E$. coli isolates have noted much higher rates $(68 \%$ to $98.6 \%)$ than reported in this study (Sabate et al., 2006, Najafi et al., 2018, Samei et al., 2016, Calhau et al., 2015, Kryger et al., 2015). In contrast, other studies reported lower rates similar to that obtained in this study ranging from $21 \%$ to $43 \%$ (Sabate et al., 2006, da Silva et al., 2017, Peerayeh et al., 2018). This variation appears to be linked in some cases to the source of isolates. The studies reporting high rates predominantly explored the rate of PAI $\mathrm{IV}_{536}$ in uropathogenic E. coli (UPEC) isolates, while the lower rates were described in enteroinvasive $E$. coli (EIEC) and commensals. The low association 
between PAI $\mathrm{IV}_{536}$ and the non-clinical isolates analyzed in this study is a welcomed finding as it could point at a lower ability of these isolates to cause disease in humans hence indicating a reduced risk from these isolates if transferred into clinical settings.

Conclusion: This study reports on the detection of PAI IV $_{536}$ in E. coli isolates from Port Harcourt, Rivers State Nigeria. The lower association of this pathogenicity marker with non-clinical isolates is a welcomed finding. A larger scale study would be ideal to properly confirm the findings of this study.

\section{REFERENCES}

Allocati, N; Masulli, M; Alexeyev, M; Dillio, C (2013). Escherichia coli in Europe: An Overview. International Journal of Environmental Research and Public Health. 10(12): 6235 - 6254.

Fratamico, PM; DebRoy, C; Liu, Y; Needleman, DS; Baranzoni, GM; Feng, P (2016). Advances in Molecular Serotyping and Subtyping of Escherichia coli. Frontiers in Microbiology. 3(7): 644.

Jang, J; Hur, HG; Sadowsky, MJ; Byappanahalli, MN; Yan, T; Ishii, S (2017). Environmental Escherichia coli: Ecology and Public Health Implications-A Review. Journal of Applied Microbiology. 123(3): 570 - 581.

Poolman, JT; Wacker, M (2015). Extraintestinal Pathogenic Escherichia coli, A Common Human Pathogen: Challenges for Vaccine Development and Progress in the Field. The Journal of Infectious Diseases. 213(1): 6 - 13.

Vila, J; Sáez-López, E; Johnson, JR; Römling, U; Dobrindt, U; Cantón, R; Giske, CG; Naas, T; Carattoli, A; Martínez-Medina, M; Bosch, J (2016). Escherichia coli: An old Friend with new Tidings. FEMS Microbiology Reviews. 40(4): 437 $-463$.

Mainil, J (2013). Escherichia coli Virulence Factors. Veterinary Immunology and Immunopathology. 152(1-2): $2-12$.

Croxen, MA; Law, RJ; Scholz, R; Keeney, KM; Wlodarska, M; Finlay, BB (2013). Recent advances in understanding Enteric Pathogenic Escherichia coli. Clinical Microbiology Reviews. 26(4): $822-828$.
Ochman, H; Jones, IB (2000). Evolutionary Dynamics of full Genome Content in Escherichia coli. The EMBO Journal. 19(24): 6637 - 6643.

Touchon, M; Hoede, C; Tenaillon, O; Barbe, V; Baeriswyl, S; Bidet, P; Bingen, E; Bonacorsi, S; Bouchier, C; Bouvet, O; Calteau, A (2009). Organised Genome Dynamics in the Escherichia coli species results in Highly Diverse adaptive paths. PLoS Genetics. 5(1):e1000344.

Chekabab, SM; Paquin-Veillette, J; Dozois, CM; Harel, J (2013). The Ecological Habitat and Transmission of Escherichia coli O157: H7. FEMS Microbiology Letters. 341(1): 1 - 2.

van Elsas, JD; Semenov, AV; Costa, R; Trevors, JT (2011). Survival of Escherichia coli in the Environment: Fundamental and Public Health Aspects. The ISME Journal. 5(2): 173.

Chaudhuri, RR; Sebaihia, M; Hobman, JL; Webber, MA; Leyton, DL; Goldberg, MD; Cunningham, AF; Scott-Tucker, A; Ferguson, PR; Thomas, CM; Frankel, G (2010). Complete Genome Sequence and Comparative Metabolic Profiling of the Prototypical Enteroaggregative Escherichia coli strain 042. PloS One. 5(1): e8801.

Perna, NT; Plunkett III, G; Burland, V; Mau, B; Glasner, JD; Rose, DJ; Mayhew, GF; Evans, PS; Gregor, J; Kirkpatrick, HA; Pósfai, G (2001). Genome Sequence of Enterohaemorrhagic Escherichia coli O157: H7. Nature. 409(6819): 529.

Oelschlaeger, TA; Hacker, J (2004). Impact of Pathogenicity Islands in Bacterial Diagnostics. APMIS. 112(11-12): 930 - 936.

Gal-Mor, O; Finlay, BB (2006). Pathogenicity Islands: A Molecular Toolbox for Bacterial Virulence. Cellular Microbiology. 8(11): 1707 - 1719.

Calhau, V; Domingues, S; Ribeiro, G; Mendonça, N; Da Silva, GJ (2015). Interplay between Pathogenicity Island Carriage, Resistance Profile and Plasmid Acquisition in Uropathogenic Escherichia coli. Journal of Medical Microbiology. 64(8): $828-835$.

Karczmarczyk, M; Walsh, C; Slowey, R; Leonard, N; Fanning, S (2011). Molecular Characterization of Multidrug-Resistant (MDR) Escherichia coli isolates from Irish Cattle Farms. Applied and 
Environmental Microbiology. 77(20): 7121 7127.

Dobrindt, U; Hochhut, B; Hentschel, U; Hacker, J (2004). Genomic Islands in Pathogenic and Environmental Microorganisms. Nature Reviews Microbiology. 2(5):414.

Sabaté, M; Moreno, E; Pérez, T; Andreu, A; Prats, G (2006). Pathogenicity Island Markers in Commensal and Uropathogenic Escherichia coli isolates. Clinical Microbiology and Infection. 12(9): $880-886$.

Koga, VL; Tomazetto, G; Cyoia, PS; Neves, MS; Vidotto, MC; Nakazato Kobayashi, RK (2014). Molecular screening of virulence genes in extraintestinal pathogenic Escherichia coli isolated from human blood culture in Brazil. BioMed Research International. 2014: 465054.

Otokunefor, K; Agbude, P; Otokunefor, TV (2018). Non-clinical Isolates as Potential Reservoirs of Antibiotic Resistance in Port Harcourt, Nigeria. The Pan African Medical Journal. 30: 167.

Cookey, TI; Otokunefor, K (2016). Poultry Environment as a Reservoir of Antimicrobial Resistant Bacteria - A Nigerian story. British Microbiology Research Journal. 17(1): 1 - 11.

Agbagwa, OE; Onyebule, CQ (2018). Microbial Population of Staphyloccocus aureus from Inanimate Surfaces in a General Hospital Environment in Rivers State, Nigeria. Journal of Applied Sciences and Environmental Management. 22(1): $124-128$.

Oliveira, CF; Paim, TG; Reiter, KC; Rieger, A; D'azevedo, PA (2014). Evaluation of Four Different DNA Extraction Methods in CoagulaseNegative Staphylococci Clinical Isolates. Revista do Instituto de Medicina Tropical de São Paulo. 56(1): $29-33$.
Otokunefor, K; Tamunokuro, E; Amadi, A (2019). Molecular detection of Mobilized Colistin Resistance (mcr-1) gene in Escherichia coli isolates from Port Harcourt, Rivers State. Journal of Applied Sciences and Environmental Management. 23(3): 401 - 405.

Najafi, A; Hasanpour, M; Askary, A; Aziemzadeh, M; Hashemi, N (2018). Distribution of Pathogenicity Island Markers and Virulence Factors in New Phylogenetic Groups of Uropathogenic Escherichia coli Isolates. Folia Microbiologica. 63(3): $335-343$.

Samei, A; Haghi, F; Zeighami, H (2016). Distribution of Pathogenicity Island Markers in Commensal and Uropathogenic Escherichia coli Isolates. Folia Microbiologica. 61(3): 261 - 268.

Calhau, V; Mendes, C; Pena, A; Mendonça, N; Da Silva, GJ (2015). Virulence and Plasmidic Resistance Determinants of Escherichia coli Isolated from Municipal and Hospital Wastewater Treatment Plants. Journal of Water and Health. 13(2): $311-318$.

Kryger, J; Burleigh, A; Christensen, M; Hopkins, W (2015). Genetic Evaluation of E. coli strains Isolated from Asymptomatic Children with Neurogenic Bladders. International Journal of Chronic Diseases. 2015: 206570.

da Silva, LC; de Mello Santos, AC; Silva, RM (2017). Uropathogenic Escherichia coli Pathogenicity Islands and Other ExPEC Virulence Genes may Contribute to the Genome Variability of Enteroinvasive E. coli. BMC Microbiology. 17(1): 68.

Peerayeh, SN; Navidinia, M; Fallah, F; Bakhshi, B; Jamali, J (2018). Pathogenicity Determinants and Epidemiology of Uropathogenic E. coli (UPEC) Strains Isolated from Children with Urinary Tract Infection (UTI) to Define Distinct Pathotypes. Biomedical Research. 29(10): 2035 - 2043. 